\title{
Analisis Kualitas Tes Ujian Akhir Semester Mata Kuliah Pengetahuan Komputer
}

\author{
Jusrianto *', Abdul Zahir ${ }^{2}$, Megawati ${ }^{3}$ \\ 1, 2, ${ }^{3}$ Universitas Cokroaminoto Palopo \\ *uncpjusrianto@gmail.com
}

\begin{abstract}
Abstrak
Tujuan penelitian ini adalah untuk mengetahui kualitas soal ujian akhir semester ganjil tahun 2016/2017 mata kuliah pengetahuan komputer di Universitas Cokroaminoto Palopo. Pendekatan yang digunakan dalam penelitian ini adalah pendekatan ex-post facto dengan jenis penelitian ini adalah deskriptif kuantitatif. Populasi dalam penelitian ini adalah soal ujian semester dan seluruh jawaban peserta didik pada ujian akhir semester ganjil tahun pelajaran 2016/20I7 yang terdiri dari lima kelas yaitu kelas TI IB, TI ID, TI IE, TI II dan Kelas Matematika IA. Teknik pengumpulan data dilakukan dengan metode dokumentasi. Data yang diperoleh dianalisis menggunakan program Anates Versi 4 dan perhitungan manual dengan bantuan Program Ms Excel. Hasil dari penelitian ini menunjukkan tingkat kesukaran soal ujian akhir semester mata kuliah Pengetahuan Komputer di Universitas Cokroaminoto Palopo tahun akademik 2016/2017 menunjukkan bahwa soal yang termasuk kategori sukar berjumlah 5 soal (I2.5\%), soal yang termasuk kategori sedang berjumlah 23 soal (57.5\%), dan soal yang termasuk kategori mudah berjumlah 12 soal (30\%), dan daya beda soal ujian akhir semester ganjil mata Pengetahuan Komputer di Universitas Cokroaminoto Palopo tahun akademik 20I6/2017 menunjukkan bahwa soal dengan daya pembeda jelek berjumlah 18 soal (45\%), soal dengan daya pembeda cukup berjumlah 16 soal (40\%), soal dengan daya pembeda baik berjumlah 6 soal (I5\%) dan tidak ada soal dengan daya pembeda yang baik sekali (0\%).
\end{abstract}

Kata Kunci: evaluasi pembelajaran; analisis soal; anates

\section{Pendahuluan}

Menurut Undang-Undang No. 20 tahun 2003, pendidikan merupakan usaha sadar dan terencana untuk mengembangkan segala potensi yang dimiliki peserta didik melalui proses pembelajaran. Pendidikan harus senantiasa bertujuan untuk mengembangkan potensi anak agar memilik akhlak mulia, berkepribadian, memiliki sikap pengendalian diri, memiliki kecerdasan dan memiliki keterampilan yang diperlukan sebagai anggota masyarakat, warga Negara dan beragama.

Kualitas pendidikan di perguruan tinggi tentunya dipengaruhi oleh peran dosen dalam pembelajaran di kampus. Dosen mengarahkan proses pembelajaran sesuai dengan tujuan pembelajaran yang telah ditetapkan. Selain mengajar dan membimbing mahasiswa dosen juga harus mengevaluasi mahasiswanya. Hal ini bertujuan untuk mengetahui sejauh mana proses pembelajaran yang dilaksanakan telah berhasil. Evaluasi adalah salah satu kegiatan yang tidak dapat dipisahkan dalam suatu program pembelajaran di kampus. (Subali, 20I2) mengemukakan bahwa evaluasi merupakan suatu program yang sistematis yang dilaksanakan untuk mengetahui tingkat keberhasilan dan efisiensi dari program yang bersangkutan. 
Evaluasi memiliki sudut pandang yang berbeda sesuai dengan bidang keahlian masingmasing. Para ahli yang menekuni bidang industri tentu objek yang dievaluasi berkaitan dengan masalah industri. Ahli yang menekuni pendidikan tentunya banyak bercerita tentang masalah pendidikan seperti kinerja, prestasi belajar, manajemen kelas, kompetensi guru, iklim akademis, dan seterusnya (Mansyur, 20I5).

Menurut Undang-undang RI nomor 20 tahun 2003 tentang sistem pendidikan nasional pasal 58 ayat I bahwa evaluasi hasil belajar peserta didik dilakukan oleh pendidik untuk memantau proses, kemajuan, dan perbaikan hasil belajar peserta didik secara berkesinambungan. Evaluasi pembelajaran bertujuan untuk meningkatkan kualitas proses belajar mengajar dengan harapan tujuan itu akan mendorong pendidik untuk mengajar lebih baik dan mendorong peserta didik terdorong untuk belajar lebih baik. Evaluasi pembelajaran berkaitan dengan penilaian hasil belajar, pengukuran, dan tes.

Proses penilaian mencakup pengumpulan bukti untuk menunjukkan pencapaian belajar peserta didik (Surapranata, 2004). Penilaian hasil belajar merupakan komponen yang sangat penting dalam kegiatan pembelajaran. Upaya meningkatkan pembelajaran dapat ditempuh dengan peningkatan kualitas sistem penilaiannya. Sistem penilaian yang baik akan mendorong guru untuk menentukan strategi mengajar yang baik dan memotivasi peserta didik untuk belajar yang lebih baik (Widoyoko, 20I I).

Pelaksanaan pengukuran sangat penting menggunakan alat ukur yang memiliki bukti kehandalan. Kehandalan alat ukur dapat dilihat dari konstruk alat ukur. Konstruksi alat ukur dapat ditelaah pada aspek materi, teknik penulisan soal dan bahasa yang digunakan. Karakteristik pengukuran adalah: (I) perbandingan antara atribut yang diukur dengan alat ukurnya; (2) hasilnya dinyatakan secara kuantitatif (3) hasilnya bersifat deskriptif (Azwar, 1999). Lebih lanjut dijelaskan oleh (Mansyur,2015) bahwa pengukuran merupakan proses pemberian angka kepada suatu atribut atau karakteristik tertentu yang dimiliki oleh orang, hal, atau objek tertentu menurut aturan atau formulasi yang jelas.

(Mardapi, 2008), tes merupakan salah satu cara untuk menaksir besarnya tingkat kemampuan manusia secara tidak langsung, yaitu melalui respons seseorang terhadap sejumlah stimulus atau pertanyaan. Tes dapat dianggap sebagai prosedur yang sistematis untuk mengamati atau mendeskripsikan karakteristik seseorang dengan menggunakan standar numerik atau sistem kategori, Secara singkat (Mansyur,2015) mendefinisikan tes sebagai sejumlah pertanyaan yang memiliki jawaban yang benar atau salah. Dilihat dari fungsinya, tes dapat dibedakan menjadi dua golongan, yaitu tes awal yang dikenal dengan pre-test dan tes akhir yang dikenal dengan istilah post-test. Pre test diberikan sebelum bahan pelajaran diajarkan yang bertujuan untuk mengetahui sejauh mana materi pelajaran yang akan diajarkan telah diketahui oleh peserta didik dan menguji tingkatan pengetahuan siswa terdapat materi yang akan disampaikan. Sedangkan tes akhir dilaksanakan untuk mengetahui sejauh mana penguasaan peserta didik terhadap materi pelajaran yang telah diajarkan dan memperoleh gambaran tentang kemampuan yang dicapai setelah berakhirnya penyampaian pelajaran.

(Arikunto, 2013) menjelaskan analisis butir soal adalah suatu prosedur yang sistematis, yang akan memberikan informasi-informasi yang sangat khusus terhadap butir tes yang kita susun. Tes dapat dijadikan sebagai alat untuk menaksir besarnya tingkat kemampuan peserta didik dalam mencapai hasil belajarnya. Sedangkan menurut Sudjana (20I2), analisis butir soal adalah pengkajian pertanyaan-pertanyaan tes agar diperoleh perangkat pertanyaan yang memiliki kualitas yang memadai. Tes ini berguna untuk mengetahui tingkat kemampuan yang telah dimiliki peserta didik. 
Anates merupakan program aplikasi atau software yang khusus digunakan untuk menganalisa tes uraian. anates memiliki kemampuan untuk menganalisa soal tes seperti; (a) Menghitung skor (asli maupun dibobot), (b) Menghitung reliabilitas tes, (c) Mengelompokkan subjek ke dalam kelompok atas atau bawa, (d) Menghitung daya pembeda, (e) Menghitung tingkat kesukaran soal, (f) Menghitung korelasi skor butir dengan skor total, (g) Menentukan kualitas pengecoh (distraktor). Keunggulan software ini sebagai program analisis butir soal adalah dapat digunakan untuk analisis butir soal bentuk uraian. Penggunaan bahasa Indonesia dalam program ini merupakan salah satu sisi kemudahan dalam penggunaannya dibandingkan dengan program lain yang menggunakan bahasa Inggris. Hasil analisis tentang skor yang diperoleh setiap tes juga dapat ditransfer ke Ms Excel untuk dihitung nilainya, maka saat mendalami program software ini sekaligus juga dapat mendalami aplikasi Ms Excel, dengan demikian pemanfaatan anates ini akan menjadi optimal dan menggunakan anates ini proses analisis tes menjadi lebih mudah, cepat, dan akurat.

Kegiatan evaluasi selalu menjadi bagian yang sangat penting untuk menentukan apakah aktivitas yang telah dilakukan dosen dan mahasiswa berhasil atau tidak. Oleh sebab itu, kegiatan evaluasi harus senantiasa dilakukan secara terencana, terprogram, dan terpercaya sehingga program pembelajaran yang telah dilaksanakan berjalan sesuai dengan tujuan yang telah ditetapkan. Dalam kegiatan evaluasi, ada empat komponen yang tidak terpisahkan, yaitu penilaian, pengukuran, dan tes. Hasil dari evaluasi yang telah dilakukan dapat digunakan untuk membuat kebijakan atau mengambil keputusan.

Sampai saat ini pembelajaran pengetahuan komputer bagi mahasiswa Universitas Cokroaminoto Palopo merupakan pelajaran yang dipandang mudah dan banyak disenangi oleh sebagian besar mahasiswa. Hal ini terbukti dari nilai rata-rata akademik yang diperoleh mahasiswa masih jauh lebih tinggi dibanding nilai-nilai mata kuliah lain.

Berdasarkan hasil wawancara terbatas kepada dosen dan mahasiswa mengenai ujian akhir semester yang telah dilaksanakan sebelumnya bahwa soal akhir semester tersebut tidak dianalisis terlebih dahulu baik secara kualitatif maupun secara kuantitatif. Sehingga ditemukanlah soal akhir semester yang terkadang terlalu susah atau terlalu mudah yang menyebabkan dosen sulit membedakan kemampuan mahasiswa. Penyebab utamanya adalah tidak adanya pengetahuan yang memadai dalam membuat soal, baik secara kualitatif maupun secara kuantitatif. Pemahaman para dosen dalam penyusun soal-soal akhir semester tersebut terhadap teori-teori pengukuran yang ada (teori tes klasik dan teori respons butir) sangat kurang. Analisis butir soal sebagai bentuk penerapan teori-teori pengukuran tersebut merupakan hal baru bagi mereka. Oleh sebab itu, diperlukan analisis terhadap tes yang akan diberikan kepada mahasiswa dengan harapan soal akhir semester tersebut cukup berkualitas sehingga hasil tes dapat merepresentasikan kemampuan mahasiswa yang sebenarnya.

\section{Metode Penelitian}

Pendekatan yang digunakan dalam penelitian ini adalah pendekatan ex-post facto dengan jenis penelitian ini adalah penelitian campuran (mixed methods). Dalam kegiatan penelitian ini peneliti tidak melakukan perlakuan apapun terhadap variable penelitian, karena kondisi variabel yang diteliti sudah tampak. Ex-post facto adalah penelitian yang dilakukan untuk meneliti variable atau peristiwa yang telah terjadi dan kemudian merunut ke belakang melalui data tersebut untuk menemukan faktor-faktor penyebab terjadinya peristiwa yang diteliti (Sugiyono, 2008). Populasi dalam penelitian ini adalah soal ujian semester dan seluruh jawaban peserta didik pada ujian akhir semester ganjil (pertama) di Universitas Cokroaminoto Palopo tahun pelajaran 2016/2017 yang terdiri dari lima kelas yaitu kelas $\mathrm{TI}$ 
IB, TI ID, TI IE, TI II, dan Matematika IA. Jumlah mahasiswa dapat dilihat pada tabel I di bawah ini.

Tabel I. Populasi dan Sampel Penelitian

\begin{tabular}{lrrrrrr}
\hline Mahasiswa & TI B & TI D & TI E & TII & MAT A & $\Sigma$ \\
\hline Laki-laki & 12 & 19 & 26 & 14 & 4 & 75 \\
Perempuan & 18 & 15 & 12 & 25 & 32 & 102 \\
\hline Jumlah & 30 & 34 & 38 & 39 & 36 & 177 \\
\hline
\end{tabular}

Teknik sampling yang digunakan untuk mendapatkan sampel dalam penelitian ini adalah population sampling yaitu populasi sekaligus sebagai sampel Karena populasi yang diteliti kurang dari 177 orang.

\section{Hasil Penelitian}

Berdasarkan teknik pengumpulan data yang diuraikan pada bab sebelumnya, data pada penelitian ini diperoleh dari dokumen-dokumen berupa daftar nama- nama peserta ujian, kisikisi soal ujian, soal ujian akhir semester ganjil, kunci jawaban soal, serta lembar jawaban mahasiswa yang mengikuti ujian. Adapun jumlah mahasiswa yang mengikuti ujian sebanyak I77 mahasiswa yang terbagi ke dalam 5 kelas, yakni: TI IB, TI ID, TI IE, TI II, dan Matematika IA.

Data yang telah dihimpun akan dijadikan acuan dalam menganalisis kualitas butir soal UAS yang lebih ditekankan pada analisis tingkat kesukaran dan daya beda soal di Universitas Cokroaminoto Palopo.

\section{Tingkat Kesukaran}

Tingkat kesukaran (difficulty level) suatu butir soal adalah proporsi atau persentase subjek yang menjawab tes tertentu dengan benar. Angka yang menunjukkan sukar atau mudahnya suatu butir soal dinamakan indeks kesukaran ( $\mathrm{P}$ ) terletak antara 0 dan I. Kriteria penentuan jenis tingkat kesukaran butir soal adalah sebagai berikut.

$$
\begin{array}{lll}
p \leq 0.30 & \Rightarrow & \text { butir soal sukar } \\
0.30<p \leq 0.70 & \Rightarrow & \text { butir soal sedang } \\
p>0.70 & \Rightarrow & \text { butir soal mudah }
\end{array}
$$

Sehingga dari hasil analisis butir soal diperoleh seperti yang terlihat pada tabel 2.

Tabel 2. Hasil Analisis Tingkat Kesukaran

\begin{tabular}{cccc}
\hline Item Butir Soal & $\begin{array}{c}\text { Jumlah Siswa yang } \\
\text { Benar }\end{array}$ & $\begin{array}{c}\text { Tingkat Kesukaran } \mathrm{p}= \\
\frac{\sum x_{i}}{S m_{1} N}\end{array}$ & Kriteria \\
\hline 1 & 140 & 0.70 & Butir soal sedang \\
\hline 2 & 131 & 0.66 & Butir soal sedang \\
\hline 3 & 117 & 0.59 & Butir soal sedang \\
\hline 4 & 64 & 0.32 & Butir soal sedang \\
\hline 5 & 90 & 0.45 & Butir soal sedang \\
\hline 6 & 157 & 0.79 & Butir soal mudah \\
\hline 7 & 158 & 0.79 & Butir soal mudah \\
\hline 8 & 149 & 0.75 & Butir soal mudah \\
\hline 9 & 79 & 0.4 & Butir soal sedang \\
\hline 10 & 145 & 0.73 & Butir soal mudah \\
\hline 11 & 120 & 0.6 & Butir soal sedang \\
\hline 12 & 53 & 0.27 & Butir soal sukar \\
\hline 13 & 105 & 0.53 & Butir soal sedang \\
\hline-9 & & \\
\hline
\end{tabular}




\begin{tabular}{|c|c|c|c|}
\hline Item Butir Soal & $\begin{array}{c}\text { Jumlah Siswa yang } \\
\text { Benar }\end{array}$ & $\begin{array}{c}\text { Tingkat Kesukaran } \mathrm{p}= \\
\frac{\sum x_{i}}{S m_{1} N}\end{array}$ & Kriteria \\
\hline 14 & 82 & 0.41 & Butir soal sedang \\
\hline 15 & 134 & 0.67 & Butir soal sedang \\
\hline 16 & 52 & 0.26 & Butir soal sukar \\
\hline 17 & 108 & 0.54 & Butir soal sedang \\
\hline 18 & 50 & 0.25 & Butir soal sukar \\
\hline 19 & 93 & 0.47 & Butir soal sedang \\
\hline 20 & 108 & 0.54 & Butir soal sedang \\
\hline 21 & $14 \mid$ & 0.71 & Butir soal mudah \\
\hline 22 & 141 & 0.71 & Butir soal mudah \\
\hline 23 & 52 & 0.26 & Butir soal sukar \\
\hline 24 & 14 & 0.07 & Butir soal sukar \\
\hline 25 & 110 & 0.55 & Butir soal sedang \\
\hline 26 & 124 & 0.62 & Butir soal sedang \\
\hline 27 & 61 & 0.31 & Butir soal sedang \\
\hline 28 & 164 & 0.82 & Butir soal mudah \\
\hline 29 & 62 & 0.31 & Butir soal sedang \\
\hline 30 & 142 & 0.71 & Butir soal mudah \\
\hline 31 & 95 & 0.48 & Butir soal sedang \\
\hline 32 & 80 & 0.4 & Butir soal sedang \\
\hline 33 & 153 & 0.77 & Butir soal mudah \\
\hline 34 & 143 & 0.72 & Butir soal mudah \\
\hline 35 & 102 & 0.51 & Butir soal sedang \\
\hline 36 & 138 & 0.69 & Butir soal sedang \\
\hline 37 & 63 & 0.32 & Butir soal sedang \\
\hline 38 & 84 & 0.42 & Butir soal sedang \\
\hline 39 & 147 & 0.74 & Butir soal mudah \\
\hline 40 & 143 & 0.72 & Butir soal mudah \\
\hline
\end{tabular}

Klasifikasi Tingkat Kesukaran soal disajikan pada tabel 3 berikut ini.

Tabel 3. Klasifikasi Tingkat Kesukaran

\begin{tabular}{cll}
\hline No. & \multicolumn{1}{c}{ Kriteria } & Item Soal \\
\hline$I$ & Butir soal sukar & $I 2, I 6, I 8,23,24$ \\
2 & Butir soal sedang & $I, 2,3,4,5,9, I I, I 3, I 4, I 5, I 7,19,20,25$, \\
& & $26,27,29,31,32,35,36,37,38$ \\
3 & Butir soal mudah & $6,7,8,10,21,22,28,30,33,34,39,40$ \\
\hline
\end{tabular}

Secara umum, sebagaimana yang ditampilkan hasil analisis dari program TAP ini, didapat mean item diffuculty sebesar 0.539 atau tingkat kesukarannya berada pada kategori sedang.

Tabel 4 Distribusi Tingkat Kesukaran Butir Soal

\begin{tabular}{cclcc}
\hline No & $\begin{array}{c}\text { Indeks } \\
\text { Kesukaran }\end{array}$ & Butir Soal & Jumlah & $\%$ \\
\hline $\mathrm{I}$ & $\begin{array}{c}\text { Sukar } \\
(0 \%-30 \%)\end{array}$ & $12,16,18,23,24$ & 5 & $12.5 \%$ \\
2 & $\begin{array}{c}\text { Sedang } \\
(31 \%-70 \%)\end{array}$ & $\begin{array}{l}1,2,3,4,5,9,11,13,14,15,17,19,20,25,26, \\
21,32,35,36,37,38\end{array}$ & 23 & $57.5 \%$ \\
3 & $\begin{array}{c}\text { Mudah } \\
(71 \%-100 \%)\end{array}$ & $6,7,8,10,21,22,28,30,33,34,39,40$ & 12 & $30 \%$ \\
& & & \\
\hline
\end{tabular}




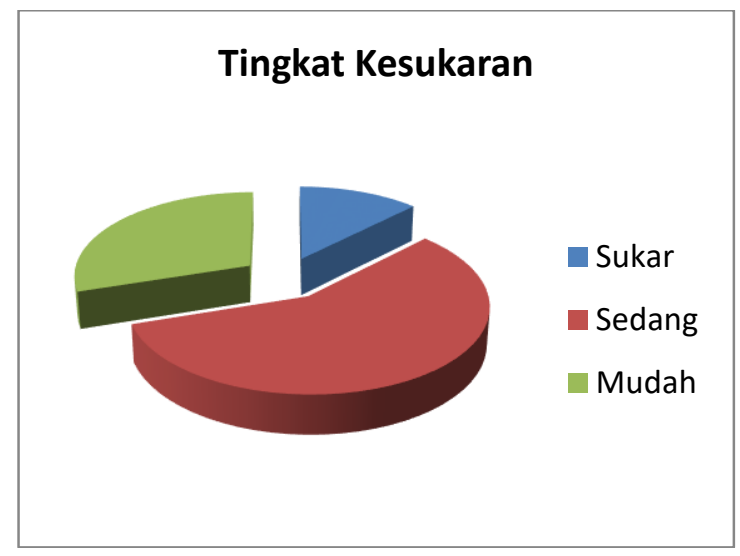

Gambar 3. Diagram Distribusi Tingkat Kesukaran Butir Soal

\section{Daya Pembeda}

Kriteria untuk daya pembeda adalah apabila 0,00 - 0,19 dikategorikan daya pembeda jelek, 0,20 - 0,39 kategori daya pembeda cukup, 0,40 - 0,69 kategori daya pembeda baik, 0,70 - I,00 kategori daya pembeda baik sekali, dan apabila bernilai negatif (-) berarti semuanya tidak baik, jadi semua butir soal yang mempunyai nilai $D$ negatif sebaiknya dibuang saja.

Penentuan kelas atas dan kelas bawah menggunakan $27 \%$ dari seluruh peserta tes. 48 orang diambil untuk kelas atas, hal yang sama pada kelas bawahnya (27\% dari 177 peserta tes adalah 48 orang). Daya beda yang diperoleh dengan menggunakan Anates V.4.0.5 pada soal UAS mata kuliah Pengetahuan Komputer dapat dilihat pada tabel di bawah ini.

Tabel 5. Daya Beda Butir Soal

\begin{tabular}{|c|c|c|}
\hline Item Butir Soal & Daya Beda & Tafsiran \\
\hline $\mathrm{I}$ & 0.06 & Jelek \\
\hline 2 & 0.15 & Jelek \\
\hline 3 & 0.1 & Jelek \\
\hline 4 & 0.33 & Cukup \\
\hline 5 & 0.33 & Cukup \\
\hline 6 & 0.02 & Jelek \\
\hline 7 & 0.17 & Jelek \\
\hline 8 & 0.29 & Cukup \\
\hline 9 & 0.54 & Baik \\
\hline 10 & 0.19 & Jelek \\
\hline $\mathrm{II}$ & 0.35 & Cukup \\
\hline 12 & 0.06 & Jelek \\
\hline 13 & 0.38 & Cukup \\
\hline 14 & 0.56 & Baik \\
\hline 15 & 0.29 & Cukup \\
\hline 16 & 0.06 & Jelek \\
\hline 17 & 0.38 & Cukup \\
\hline 18 & 0.31 & Cukup \\
\hline 19 & 0.1 & Jelek \\
\hline 20 & 0.1 & Jelek \\
\hline 21 & 0.19 & Jelek \\
\hline 22 & 0.19 & Jelek \\
\hline 23 & 0.23 & Cukup \\
\hline 24 & 0.1 & Jelek \\
\hline 25 & 0.54 & Baik \\
\hline 26 & 0.33 & Cukup \\
\hline 27 & 0.23 & Cukup \\
\hline
\end{tabular}




\begin{tabular}{ccc}
\hline Item Butir Soal & Daya Beda & Tafsiran \\
\hline 28 & 0.04 & Jelek \\
\hline 29 & 0.42 & Baik \\
\hline 30 & 0.31 & Cukup \\
\hline 31 & 0.46 & Baik \\
\hline 32 & 0.27 & Cukup \\
\hline 33 & 0.15 & Jelek \\
\hline 34 & 0.35 & Cukup \\
\hline 35 & 0.42 & Baik \\
\hline 36 & 0.13 & Jelek \\
\hline 37 & 0.35 & Cukup \\
\hline 38 & 0.31 & Cukup \\
\hline 39 & 0.06 & Jelek \\
\hline 40 & 0.19 & Jelek \\
\hline
\end{tabular}

Berdasarkan hasil analisis data yang dilakukan pada butir soal di atas dengan menggunakan program komputer dapat diketahui bahwa soal dengan daya pembeda jelek berjumlah 18 soal, soal dengan daya pembeda cukup berjumlah 16 soal, soal dengan daya pembeda baik berjumlah 6 soal dan soal dengan daya pembeda yang baik sekali berjumlah 0 soal. Berikut adalah tabel distribusi daya pembeda:

Tabel 6. Distribusi Daya Beda Butir Soal

\begin{tabular}{cclcc}
\hline No & Daya Pembeda & Butir Soal & Jumlah & $\%$ \\
\hline $\mathbf{I}$ & Jelek & $\mathrm{I}, 2,3,6,7,10,12,16,19,20,21,22,24,28$, & 18 & $45 \%$ \\
& $(0,00-0,19)$ & $33,36,39,40$ & & \\
$\mathbf{2}$ & $\begin{array}{c}\text { Cukup } \\
(0,20-0,39)\end{array}$ & $\begin{array}{l}4,5,8,11,13,15,17,18,23,26,27,30,32, \\
34,37,38\end{array}$ & 16 & $40 \%$ \\
$\mathbf{3}$ & $\begin{array}{c}\text { Baik } \\
(0,40-0,69)\end{array}$ & $9,14,25,29,31,35$ & 6 & $15 \%$ \\
$\mathbf{4}$ & $\begin{array}{c}\text { Baik Sekali } \\
(0,70-1,00)\end{array}$ & 0 & 0 & $0 \%$ \\
& & & \\
\hline
\end{tabular}

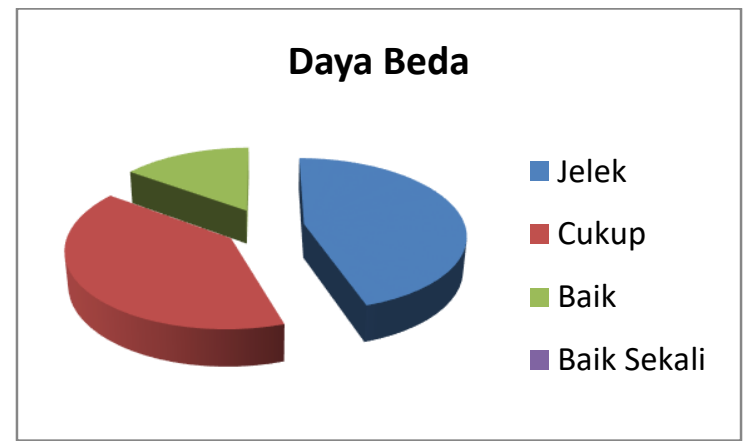

Gambar 2. Diagram distribusi daya pembeda soal

\section{Pembahasan Hasil Penelitian}

Penelitian ini bertujuan untuk mengetahui kualitas butir soal ujian akhir semester mata kuliah Pengetahuan Komputer semester ganjil tahun akademik 2016/2017. Kualitas butir soal tersebut dapat dilihat melalui unsur tingkat kesukaran dan daya pembeda.

\section{Tingkat Kesukaran}

Oller (dalam Nurgiantoro, 2010) berpendapat tingkat kesukaran dapat didefenisikan seberapa besar suatu butir soal memberi fasilitas atau kemudahan bagi peserta didik. Tingkat 
kesukaran adalah presentase mahasiswa yang menjawab dengan benar suatu soal, juga disebut sebagai nilai P. Rentangnya adalah dari $0 \%-100 \%$, semakin tinggi nilai $\mathrm{P}$ semakin mudah soal tersebut.

Tingkat kesukaran mengacu pada pengukuran seberapa besar derajat kesukaran suatu soal. $\mathrm{Hal}$ ini dilihat dari proporsi mahasiswa yang menjawab benar untuk butir soal, yang diperoleh dengan cara menentukan rata-rata skor mahasiswa pada satu soal dibagi dengan skor maksimum pada butir soal tersebut. Analisis tingkat kesukaran soal dapat dilihat berdasarkan indeks kesukaran. Apabila suatu soal memiliki tingkat kesukaran sedang dengan indeks kesukaran 0,3I - 0,70, maka dapat dikatakan soal tersebut baik.

Hasil analisis tingkat kesukaran soal ujian akhir semester soal ujian akhir semester ganjil mata kuliah Pengetahuan Komputer di Universitas Cokroaminoto Palopo tahun akademik 2016/2017 menunjukkan bahwa soal yang termasuk kategori sukar berjumlah 5 soal (I2.5\%), soal yang termasuk kategori sedang berjumlah 23 soal (57.5\%), dan soal yang termasuk kategori mudah berjumlah 12 soal (30\%).

Hasil penelitian ini sesuai dengan kajian teori yang menyatakan bahwa salah satu analisis yang harus dilakukan adalah analisis terhadap tingkat kesukaran. Soal yang baik adalah soal yang tidak terlalu mudah atau tidak terlalu sukar. Jika suatu soal memiliki tingkat kesukaran seimbang (proporsional), maka dapat dikatakan bahwa soal tersebut baik.

Berdasarkan uraian di atas dapat disimpulkan bahwa soal ujian akhir semester mata kuliah Pengetahuan Komputer di Universitas Cokroaminoto Palopo tahun akademik 2016/2017 merupakan bentuk soal yang cukup baik berdasarkan tingkat kesukarannya karena banyaknya soal sedang yaitu $57,5 \%$.

Butir soal yang termasuk kategori sedang dimasukkan dalam bank soal dan dapat dipergunakan kembali sebagai alat evaluasi mahasiswa pada waktu yang akan datang. Butir soal yang termasuk kategori mudah atau sukar perlu dilakukan tindak lanjut yaitu soal tersebut ditelusuri sehingga bisa diketahui faktor penyebab kegagalan soal tersebut. Sehingga soal tersebut dapat direvisi dan diperbaiki untuk kemudian diujikan kembali pada tes yang akan datang.

\section{Daya Pembeda}

Daya pembeda menunjukkan sejauh mana tiap butir soal mampu membedakan mahasiswa yang menguasai materi dan mahasiswa yang tidak menguasai materi. Analisis daya pembeda soal dapat dilihat berdasarkan indeks diskriminasi. Hasil analisis daya pembeda soal ujian akhir semester ganjil mata kuliah Pengetahuan Komputer di Universitas Cokroaminoto Palopo tahun akademik 2016/2017 menunjukkan bahwa soal dengan daya pembeda jelek berjumlah I8 soal (45\%), soal dengan daya pembeda cukup berjumlah 16 soal $(40 \%)$, soal dengan daya pembeda baik berjumlah 6 soal (I5\%) dan tidak ada soal dengan daya pembeda yang baik sekali ( $0 \%)$.

Hasil penelitian tersebut sudah sesuai dengan kajian teori yang menyatakan bahwa salah satu analisis yang harus dilakukan untuk mengetahui apakah masing-masing butir soal dapat dikatakan baik sebagai alat evaluasi adalah analisis terhadap daya pembeda. Semakin tinggi koefisien daya pembeda suatu butir soal, semakin mampu butir soal tersebut membedakan antara peserta didik yang menguasai kompetensi materi dengan peserta didik yang kurang menguasai kompetensi materi. Jika semua atau sebagian besar mahasiswa pandai dapat menjawab dengan benar suatu soal maka daya pembeda soal tersebut tinggi.

Berdasarkan uraian di atas dapat disimpulkan bahwa soal ujian akhir semester ganjil mata Pengetahuan Komputer di Universitas Cokroaminoto Palopo tahun akademik 2016/2017 
merupakan soal yang cukup baik. Artinya soal tersebut telah dapat membedakan antara mahasiswa yang sudah menguasai kompetensi materi dengan mahasiswa yang belum menguasai kompetensi materi. Butir soal yang daya pembedanya cukup sebaiknya dilakukan perbaikan agar menjadi soal yang baik sedangkan butir soal yang daya pembedanya kurang baik harus dilakukan perbaikan dengan menelusuri penyebab kegagalan tersebut. Daya pembeda soal dapat digunakan untuk meningkatkan kualitas soal berdasarkan data empirik dan analisis butir. Indeks daya pembeda dapat menunjukkan apakah soal tersebut baik dan diterima, harus direvisi atau harus dibuang.

\section{Kesimpulan}

Berdasarkan hasil penelitian dan pembahasan, maka dapat ditarik kesimpulan sebagai berikut: Tingkat kesukaran soal ujian akhir semester mata kuliah Pengetahuan Komputer di Universitas Cokroaminoto Palopo tahun akademik 2016/2017 menunjukkan bahwa soal yang termasuk kategori sukar berjumlah 5 soal (I2.5\%), soal yang termasuk kategori sedang berjumlah 23 soal (57.5\%), dan soal yang termasuk kategori mudah berjumlah 12 soal (30\%), dan daya beda soal ujian akhir semester ganjil mata Pengetahuan Komputer di Universitas Cokroaminoto Palopo tahun akademik 2016/2017 menunjukkan bahwa soal dengan daya pembeda jelek berjumlah 18 soal (45\%), soal dengan daya pembeda cukup berjumlah 16 soal (40\%), soal dengan daya pembeda baik berjumlah 6 soal (15\%) dan tidak ada soal dengan daya pembeda yang baik sekali (0\%).

\section{Referensi}

Arikunto, S. (2013). Dasar-Dasar Evaluasi Pendidikan. Jakarta: PT Bumi aksara

Azwar, S. (1999). Dasar-dasar Psikometri. Yogyakarta: Pustaka Pelajar.

Bambang, S. (2012). Prinsip Asesmen \& Evaluasi Pembelajaran. Yogyakarta: UNY Press.

Mansyur. (20I5). Asesmen Pembelajaran di Sekolah. Yogyakarta: Multi Pressindo.

Mardapi, D. (2008). Teknik Penyusunan Instrumen Tes dan Nontes. Yogyakarta: Mitra Cendekia. Nurgiantoro, B. (2010). Penilaian Pembelajaran Bahasa. Yogyakarta: BPFE-Yogyakarta Sugiyono. (2008). Metode Penelitian Administrasi: dilengkapi dengan metode $R \& D$. Bandung: Alfabeta.

Undang - Undang Republik Indonesia. (2003). Undang-undang Republik Indonesia, Nomor 20, tahun 2003, tentang Sistem Pendidikan Nasional

Sudjana, N. (20I2). Penilaian Hasil Proses Belajar Mengajar. Bandung: PT Remaja Rosdakarya. Surapranata, S. (2004). Panduan Penulisan Tes Tertulis. Bandung: Rosda Karya.

Widoyoko, S. E. P. (20I I). Evaluasi program pembelajaran. Yogyakarta: Pustaka Pelajar.

Zulaiha, R. (2008). Analisis Soal Secara Manual. Jakarta: Puspendik. 